\title{
Self-Efficacy in Teaching Multicultural Students in Academia
}

\author{
Revital Sela-Shayovitz ${ }^{1} \&$ Idit Finkelstein ${ }^{2}$ \\ ${ }^{1}$ Revital Sela-Shayovitz, Ono Academic College and the Institute of Criminology, Faculty of Law, The Hebrew \\ University of Jerusalem, Israel \\ ${ }^{2}$ Idit Finkelstein, Ono Academic College, Israel \\ Correspondence: Revital Sela-Shayovitz, Ono Academic College and the Institute of Criminology, Faculty of Law, \\ The Hebrew University of Jerusalem, Israel. E-mail: revital28s@gmail.com
}

Received: October 27, 2019

Accepted: December 8, 2019

Online Published: December 11, 2019

doi:10.5430/ijhe.v9n1p159

URL: https://doi.org/10.5430/ijhe.v9n1p159

\begin{abstract}
The present study examined self-efficacy in teaching multicultural student populations in academic settings. Three indicators were used to examine teacher self-efficacy: teachers' self-efficacy beliefs regarding teaching multicultural student groups (TSEB), teachers' efficacy in the academic organization (TEAO) and professional teaching efficacy in multicultural student groups (PTEM). Data were obtained from a questionnaire administered anonymously to faculty members teaching in four faculties: humanities, law, health professions and business administration. The findings revealed a significant correlation between TSEB and PTEM. Teachers who reported positive beliefs and attitudes toward teaching multicultural student groups in academia also reported high efficacy in teaching these groups. Furthermore, TEAO correlated significantly with PTEM. The article discusses the research findings and examines future research directions.
\end{abstract}

Keywords: professional self-efficacy, multicultural teaching, academia

\section{Introduction}

Teaching multicultural student groups is a common phenomenon in many countries in the globalization era. Cultural diversity of students in academia has many advantages, for example, at the social level student cultural diversity can help reduce social disparities and better prepare students for the labor market. It can also contribute to reducing social tensions and conflicts and to increasing social solidarity (Bergan \& Damian, 2010).

Nevertheless, higher education faces many challenges in teaching a culturally diverse student population. Studies point to certain key factors that create barriers for students from disadvantaged groups in society: difficulty adjusting to academia, language comprehension difficulties, large gaps in prior knowledge and a tendency to avoid collaboration with students from other social groups (Ippolito, 2007; Mena \& Rogers, 2017). Therefore, higher education institutions play a key role in developing skills and intercultural sensitivity and modify their pedagogy and attitude towards culturally diverse students (Bergan \& Damian, 2010). Indeed, over the past decade many academic organizations have developed multicultural education programs and invested efforts to increase students' sense of on-campus belonging and inclusivity (Winkle-Wagner \& Locks 2014).

There is a growing body of literature about the role of teacher self-efficacy. Studies have shown that teachers with high self-efficacy are more supportive of their students and take responsibility for student achievements. Moreover, they also invest in diversifying their teaching methods and collaborate with colleagues (Deemer, 2004; Betoret, 2006; Guo et al., 2014). To date, the majority of studies have focused on teacher self-efficacy in school, while studies about teaching multicultural student groups in academia are all but nonexistent. This paper attempts to address this important aspect by expanding the perspective to self-efficacy in academia, with emphasis on self-efficacy in teaching multicultural student groups.

\section{Literature Review}

\subsection{Multicultural Education in Academia}

The multicultural education approach was influenced to a large extent by the rise of the human rights movement in the 1960s. This approach has significantly expanded in recent decades in the wake of globalization, and is now a central theme in the educational discourse of many Western countries (Ndura \& Dogbevia, 2013). It aspires to inculcate in students diverse cultural components and to instill pluralistic perspectives needed to effectively function 
in a multicultural and democratic society. Furthermore, multicultural education seeks to integrate students from underprivileged populations previously excluded from higher education (Ben-Rafael, 2008; Spring, 2017). The approach emphasizes social tolerance and the rejection of judgmental attitudes towards the Other. It also has also more exalted goals, and its implementation is the cornerstone of global economic growth, empowerment, and social cohesion (Banks \& Banks, 2019).

Multicultural education also aims to develop students' knowledge and skills which will enable them to function within their own community and in a global society (Banks \& Banks, 2019). Kimmel \& Volet (2012) found three key elements that influence students' intercultural encounters: language skills, academic proficiencies and creating the sense of a cohort group among students. The latter in particular improves familiarity with other students and contributes to intercultural interactions. Furthermore, students' sense of belonging affects both their experience and level of performance, with the former found to be vital, mainly among minority students, in improving their ability to contend with learning challenges and remain in academia (Murphey and Zirkel 2015, Strayhorn 2012).

Multicultural education difficulties in academia do not only involve students, as they affect all members of the academic community in a variety of areas. Academic institutions must examine their ability to adapt to students from diverse cultural groups and to multicultural education. The research literature describes in detail activities carried out by academic institutions in accordance with the multicultural approach to education. These include the integration of multicultural content into course syllabi, the use of appropriate learning strategies, student assessment and social dynamics arising from the intercultural encounter (Mena \& Rogers, 2017). The self-efficacy of teaching multicultural student groups in academia is influenced by the teachers' previous education and academic experience, as well as by their worldview. It includes effective educational activity within a variety of cultures, integration of multicultural aspects in teaching, and coping with student difficulties and with the social conflicts that may arise in the encounter. Researchers stress the importance of developing teachers' multicultural self-efficacy for optimal engagement with diverse populations (Prieto, 2012; Guy, 2010). For example, by training faculty members, providing tools and developing the skills they need for meaningful teaching of multicultural student groups.

Organizational climate is another important component of self-efficacy teaching multicultural students. An academic organizational culture that appreciates the ethnic and social diversity of its faculty members may contribute to the creation of a climate that facilitates the development of multicultural teaching. Additional key organizational climate factors are the integration of multicultural issues into the curriculum and the development of programs to improve multicultural teaching. These can directly help assess the strengths and weaknesses of the curriculum in addressing multicultural issues (Adams, Bell, \& Griffin, 2007).

\subsection{Self-efficacy}

The self-efficacy approach is based on Bandura's social-cognitive theory (Bandura, 1986, 1993). Self-efficacy is multidimensional concept and combines the beliefs and knowledge of individuals with their ability to perform tasks (Zimmerman \& Cleary, 2006). It is also associated with psychological factors such as anxiety, self-image, and motivation, which affect individual behavior and the ability to demonstrate achievement (Friedman \& Kass, 2000). The underlying assumption of this approach is that self-efficacy determines how individuals relate to the opportunities for success they encounter, the formulation of goals and the values according to which they act, and their perception of the limitations and difficulties they face. Self-efficacy is not monolithic however, and may differ from one domain to the next (Bandura, 2006). It is therefore a central and important component of personality, affecting the behavior and the manner in which individuals utilize their skills (Bandura, 2006, 2000; Schunk \& Meece, 2006). Studies have shown that individuals with a high level of self-efficacy are characterized by higher motivation and persistence in performing tasks compared to those with low self-efficacy (Bandura, 2006, 2000). Professional self-efficacy is key to understanding motivation processes and the commitment level of professionals to their work. Thus, it incorporates individuals' attitudes and beliefs in their ability to accomplish their professional goals (Bandura, 1997, 2000). According to the self-efficacy approach, individuals with a high level of self-efficacy have positive attitudes towards professional goals, believe in their professional abilities and invest effort in achieving their professional goals (Judge et al., 2007; Kanfer, 1990).

Self-efficacy has been extensively studied with regard to professional skills. Research findings show that professional self-efficacy affects the individual's adaptation level to the workplace and to changes in the professional field (Morey \& Ma, 2016; Saks, 1995). It also influences decision making and the ability to persevere in coping with professional difficulties (Bandura, 1997, 2000). Individuals with high self-efficacy in the professional field tend to achieve valued goals and exhibit the ability to cope with problems and difficulties. Achieving professional objectives 
at work also creates a sense of satisfaction and reward for the effort invested (Borgogni et al., 2013; Peng \& Mao, 2015). Nevertheless, studies have indicated that the organizational climate in the workplace and the complexity of the tasks that must be performed have a moderating effect on the relationship between professional self-efficacy and the quality of work performance (Chen et al., 2000; Stajcovic \& Luthans, 1998).

In the teaching field self-efficacy has received broad research attention. Similar to other professions, self-efficacy in teaching includes three main components: personal efficacy (beliefs and attitudes towards the teaching profession), efficacy within the organization (interpersonal relationships and support of the organization) and professional efficacy (the ability of individuals to carry out the tasks required in teaching) (Friedman \& Kass, 2000; Wang, Hall, \& Rahimi, 2015). Findings show that teacher self-efficacy is related to the quality of teaching and the level of support they provide to their students (Guo et al., 2014). Teachers with a high level of self-efficacy use a variety of challenging teaching methods to advance their students (Deemer, 2014). They set high teaching goals for themselves and invest effort in coping with the difficulties they encounter. They are more willing to accept innovations in the teaching field and establish productive collaborations with peer educators (Betoret, 2006). Teachers with a high level of professional efficacy also tend to assume responsibility for their students' achievements and are prepared to cope with their students' failure (Goddard \& Goddard, 2001; Ross, 1995; Sela-Shayovitz, 2009). Furthermore, teachers' self-efficacy level changes in relation to individual students in their classrooms (Zee, Koomen, et al., 2016). At the same time, significant differences were not found between the socio-demographic variables of gender, teaching seniority and ethnicity and teachers' self-efficacy perception (Tschannen-Moran \& Woolfolk-Hoy, 2007). An important aspect of self-efficacy has to do with the organizational climate and the quality of support provided by colleagues and the organization as a whole. Studies have shown high teacher efficacy in schools characterized by cooperation and support for teachers. By contrast, teachers' self-efficacy level was found to be low in schools characterized by lack of cooperation and support for the professional staff, with teachers less willing to invest effort in coping with their students' failures (Duran \& Duran, 2005; Goddard, 2001, 2006).

\section{Method}

A review of the research literature indicates that multiculturalism is a central theme in educational discourse. Among other things, multicultural student groups in academia challenge lecturers who must address academic, cultural and social difficulties. To date, professional self-efficacy in teaching has been examined mainly with regard to school teachers, and has hardly been studied in the academic setting. The present study contributes to the literature through analysis of the self-efficacy of lecturers in academia teaching multicultural student groups. The present study has three main objectives:

1. Examine the association between academic teachers' self-efficacy beliefs (TSEB) and professional teaching efficacy in multicultural student groups (PTEM).

2. Examine the association between teachers' efficacy in the academic organization (TEAO) and PTEM.

3. Examine the relationship between socio-demographic variables (age, gender, teaching seniority, academic degree) and PTEM.

\subsection{Sample}

The sample consisted of 92 faculty members who teach at the Ono Academic College in Israel. The college has a multicultural academic agenda and endeavors to provide academic education to students belonging to the largest minority populations in Israel, including men and women from the ultra-Orthodox community, of Ethiopian ethnicity and of Arab nationality, as well as individuals with developmental and learning disabilities. Therefore, Ono Academic College is a good laboratory for analyzing academic teaching efficacy in multicultural student groups.

\subsection{Instrument}

Data were collected using an anonymous self-report questionnaire, based on previous studies of teacher self-efficacy (Friedman \& Kass, 2000; Gibson \& Dembo, 1984) and adapted to teaching in academia. The first part of the questionnaire addressed background variables: age, gender, teaching seniority, academic degree and academic affiliation (full-time faculty member or adjunct lecturer). The second part examined the teacher's self-efficacy for academic teaching in multicultural classes. The self-efficacy questionnaire included 21 items answered on a five-point Likert-type scale $(1=$ Not at all; $5=$ To a great extent). Some items were formulated to describe high self-efficacy and others to describe low self-efficacy. The items describing low self-efficacy were reversed during data processing. Confirmatory factor analysis was conducted with Oblimin rotation, accounting for $82.4 \%$ of the variance. The three indicators were: 
1. TSEB: teachers' self-efficacy beliefs regarding teaching multicultural student groups. The variable was assessed using six items (e.g., "I believe that teaching multicultural groups has important social value" and "The dialogue that takes place in multicultural classes is important for shattering social stereotypes"). Cronbach's alpha coefficient for internal consistency was 0.89 .

2. TEAO: teachers' efficacy in the academic organization. This indicator reflects teachers' perceptions of the extent to which they receive support and cooperation from the academic organization. The variable was assessed using 7 items (e.g., "There is good cooperation between faculty members in dealing with multicultural teaching problems" and "The faculty discusses multicultural issues"). The coefficient of reliability of this factor was 0.83 .

3. PTEM: professional teaching efficacy in multicultural student groups. The indicator examined teachers' perceived ability to cope effectively with the tasks required in teaching multicultural classes. The variable was assessed using 8 items (e.g., "I succeed in integrating aspects of multiculturalism in my courses" and "I feel satisfaction teaching multicultural groups of students"). Cronbach's alpha for this scale was 0.83 .

During data processing participant scores were calculated for each of the three measures of self-efficacy, based on the average of the responses to items in each indicator.

Table 1. Participant Characteristics (in percentages)

\begin{tabular}{ccc}
\hline Variable & & $(\mathrm{N}=92)$ \\
\hline Gender & Men & 53.2 \\
Age & Women & 46.8 \\
& M & 47.2 \\
Education & SD & 0.99 \\
& MA & 29.3 \\
Affiliation & PhD & 70.7 \\
& Tenure track & 47.8 \\
Professional seniority & Adjunct lecturers & 52.2 \\
& M & 11.5 \\
Faculty & SD & 1.08 \\
& Humanities & 67.3 \\
& Law & 17.3 \\
& Business & 7.6 \\
& Administration & \\
TSEB & Health Professions & 4.3 \\
& M & 4.3 \\
TEAO & SD & 0.69 \\
& M & 3.14 \\
& SD & 0.9 \\
& M & 4.09 \\
& SD & 0.74 \\
& &
\end{tabular}

Table 1 presents the participants' characteristics and a description of the variables. The sample consisted of academic lecturers, $53.2 \%$ men and $46.8 \%$ women. The participants' age was between $30-74$ years $(\mathrm{M}=47.2 \mathrm{SD}=0.99)$. Participants' professional seniority ranged between 1 to 45 years $(\mathrm{M}=11.5, \mathrm{SD}=1.08)$. About half the participants $(47.8 \%)$ were tenure-track faculty members and the rest were adjunct lecturers $(52.2 \%)$. Most of the participants (70.7\%) earned a doctoral degree and 29.3\%a master's degree. About two-thirds of the participants taught in the Faculty of Humanities, $17.3 \%$ in the Faculty of Law and a small percentage in the faculties of Business Administration (7.6\%) and Health Professions (4.3\%). The data show that among the self-efficacy indicators TSEB 
achieved the highest score $(\mathrm{M}=4.3, \mathrm{SD}=0.69)$. Similarly, PTEM level was found to be relatively high $(\mathrm{M}=4.09$, $\mathrm{SD}=0.74)$, however TEAO level was low $(\mathrm{M}=3.1, \mathrm{SD}=0.9)$.

\subsection{Analytical Strategies}

Data were analyzed at two levels: at the first level the correlations between the three indicators of self-efficacy and the socio-demographic variables were assessed using Pearson correlation coefficients. In addition, a one-way ANOVA with Bonferroni post hoc analysis was conducted to examine the mean differences between the groups of faculty members on the three self-efficacy indicators. At the second level the analysis was conducted using a stepwise regression to examine how the indicators predict the efficacy of teaching multicultural student groups. Based on first-level analysis results, only variables associated with a $\mathrm{p}$ value of $<0.05$ were included in the regression models. Accordingly, the first model assessed TSEB and the second considered TSEB and faculty. In the third model we entered TSEB, faculty and TEAO, and the last model included TSEB, TEAO, academic affiliation, gender, age and teaching seniority.

\section{Results}

The findings presented in Table 2 show that gender is significantly associated with TSEB $(r=-.02, p<.05)$, and that the affiliation variable correlates significantly with TEAO and PTEM $(r=-.0, p<.001 ; r=-.02, p<.001$, respectively). A significant correlation was found between TSEB and PTEM, such that the higher the level of belief and the more positive the attitude about teaching multicultural groups, the higher the teacher's professional teaching efficacy in multicultural student groups $(\mathrm{r}=.69, \mathrm{p}<.001)$. The findings also point to a positive and significant correlation between SEAO and PTEM, such that respondents who reported receiving support and cooperation from the academic organization also reported high levels of professional teaching efficacy in multicultural student groups $(\mathrm{r}=.34, \mathrm{p}=0.01)$.

Table 2. Summary of Correlations between Indicators of Professional Teaching Efficacy in Multicultural Student Groups and Socio-Demographic Variables

\begin{tabular}{cccc}
\hline Variable & TSEB & TEAO & PTEM \\
\hline Gender & $0.0^{*}$ & $0.0-$ & 0.1 \\
Age & $0.28^{*}$ & $0.0-$ & $0.0-$ \\
Education & $0.1-$ & 0.22 & $0.02-$ \\
Affiliation & 0.06 & $-0.3^{* *}$ & $0.21^{* *}$ \\
Professional & 0.08 & $0.07-$ & $0.08-$ \\
seniority & & & $-0.5^{* *}$ \\
Faculty & $-0.3^{* *}$ & $0.04-$ & $0.69^{* *}$ \\
TSEB & - & $0.26^{*}$ & $0.34^{* *}$ \\
TEAO & - & - & \\
\hline
\end{tabular}

$* \mathrm{p}<.05 \quad * * \mathrm{p}<.01$

Table 3 shows the results of the regression models, suggesting that the variables TSEB, TEAO, faculty, and academic affiliation correlated significantly with PTEM. These four variables together explained $61 \%$ of the variance in PTEM. The stepwise regression analyses suggest that the TSEB indicator (e.g., teachers' attitudes and beliefs about teaching multicultural student groups) explains most of the variance (47\%). The faculty variable adds $10 \%$ to the explained variance. In other words, belonging to a particular faculty predicts $10 \%$ of the variance in professional teaching efficacy in multicultural student groups. Furthermore, efficacy within the organization (e.g., support and cooperation) predicts $2 \%$ of the explained variance, and academic affiliation (full-time faculty member vs. adjunct lecturer) predicts $2 \%$ of the variance in PTEM. 
Table 3. Summary of Regression Model Coefficients for Professional Teaching Efficacy in Multicultural Student Groups

\begin{tabular}{cccc}
\hline Variable & PTEM & & \\
\hline & $\beta$ & $(S . E)$ & $\mathrm{RSq}$ \\
TSEB & $0.5^{* *}$ & 0.4 & 0.47 \\
Faculty & $-0.29^{* *}$ & 0.05 & 0.57 \\
TEAO & $0.02^{*}$ & 0.05 & 0.59 \\
Affiliation & $* 0.18$ & 0.01 & 0.61 \\
\hline
\end{tabular}

$* \mathrm{p}<.05 \quad * * \mathrm{p}<.01$

\section{Discussion}

While increasing attention is being paid to teacher self-efficacy in school, little is known about this phenomenon in academia. The present study provides new insights and knowledge about teacher self-efficacy in an academic setting, particularly in teaching a multicultural student population. Several findings are noteworthy.

The study results show a significant correlation between TSEB and PTEM. Lecturers in academia who reported positive attitudes and beliefs about teaching a multicultural student population also reported high levels of professional efficacy in teaching this population. Moreover, lecturers with more positive attitudes also reported a willingness to invest efforts in order to achieve multicultural teaching goals. This is corroborated by research literature which underscores the relationship between self-efficacy and professionals' commitment level to their work. Thus, previous studies have shown that individuals with high self-efficacy invest greater effort in achieving professional goals and are able to cope with professional difficulties (Bandura, 2000; Judge et al., 2007; Kanfer, 1990). Furthermore, teacher self-efficacy was found to be related to quality of teaching and the degree of support extended to students. Teachers with high self-efficacy teach in a more challenging way, use a variety of teaching methods and are more supportive of their students (Deemer, 2014; Guo et al., 2014).

The present study showed that teacher efficacy in the academic organization significantly contributes to professional self-efficacy of lecturers teaching multicultural student groups, such that the higher the level of cooperation and support received from the academic organization, the higher the level of professional self-efficacy in teaching multicultural groups. These findings emphasize the importance of cultivating relationships between academic faculty members, which increases support and cooperation within the academic organization. Thus, teacher efficacy in the organization was found to play a key role in lecturer self-efficacy: lecturer perception of teaching self-efficacy was shown to be high in academic organizations characterized by collaboration with and support of the teaching faculty (Duran \& Duran, 2005; Goddard, 2001, 2002; Tobin et al., 2006).

At the same time, the level of efficacy within the organization was found to make a relatively small contribution to predicting professional teaching efficacy in teaching multicultural student groups. This may be due to the high percentage of adjunct lecturers in the sample (52.2\%). The analysis showed a significantly lower self-efficacy level among adjunct lecturers in the organization compared to tenure-track faculty members. This suggests that adjunct lecturers may be less involved in faculty activities (e.g., research seminars, conferences), and therefore less exposed to professional academic discourse about teaching multicultural students.

The study results show that the socio-demographic variables of gender, age and seniority did not significantly contribute to lecturer self-efficacy teaching multicultural student groups. Similarly, significant differences were not found in lecturer self-efficacy levels teaching multicultural students between lecturers with a master's and those with a doctoral degree. These findings are consistent with previous studies which showed that faculty member gender and seniority are not significantly correlated with professional teaching efficacy (Tschannen-Moran \& Woolfolk-Hoy, 2007).

\section{Conclusions}

The findings have several theoretical implications. First, since little if any research has examined lecturer self-efficacy in teaching multicultural student groups, the study contributes to the existing corpus of knowledge by extending the focus to lecturer self-efficacy in teaching multicultural groups of students in academia. Moreover, the study provides further insights into the role of lecturer self-efficacy in academic organizations. 
The findings also have important practical implications. The study attests to the significance of cooperation and supportive relationships within the academic organization. It suggests that conducting a professional dialog about teaching multicultural students within the framework of faculty seminars and meetings can improve the level of professional self-efficacy among lecturers teaching multicultural student groups.

The findings also suggest that academic departments should act to strengthen adjunct faculty members' participation in academic activities. Their engagement in the academic discourse taking place in academic departments and faculties may help them contend with the difficulties encountered in teaching multicultural student groups and contribute to enhancing their self-efficacy level. Scholars have noted that the multicultural commitment of faculty heads can promote discourse on this topic and contribute to increased cooperation in dealing addressing teaching difficulties (Adams, 2007). The research literature also emphasizes the importance of training faculty members in multicultural teaching multicultural student groups, providing the tools and skills needed to improve their work with diverse populations (Prieto, 2012; Guy, 2010).

Limitations and Future Research - The present study has several limitations, first, the relatively small research sample. Expanding the sample size may contribute to better understanding multicultural teacher self-efficacy in academia. Second, the differences between tenure-track and adjunct faculty members in teaching a multicultural student population indicate that further research is required on this topic. Expanding the analysis to the relationship between participation in faculty activities and self-efficacy in teaching multicultural student groups can enhance our knowledge about this topic.

\section{References}

Adams, M., Bell, L.A., \& Griffin, P. (Eds.). (2007). Teaching for diversity and social justice: a sourcebook (2nd $E d$.). New York: Routledge. https://doi.org/10.4324/9780203940822

Ben-Rafael, A. (2008). Israel: From pluralism to multiculturalism. Social Issues in Israel, 6, 120-94.

Bandura, A. (1997). Self-efficacy: The exercise of control. New York, NY: W.H. Freeman.

Bandura, A. (2000). Cultivate self-efficacy for personal and organizational Effectiveness. In E. A. Locke (Ed.), Handbook of principles of organization behavior. (pp. 120-136). Oxford, UK: Blackwell.

Bandura, A. (2006). Guide for constructing self-efficacy scales. In F. Pajares \& T. Urdan (Eds.), Adolescence and education: Vol. 5. Self efficacy and adolescence (pp. 307-337). Greenwich, CT: Information Age

Banks, J. A. \& C. A. McGee Banks (Eds.). (2001). Multicultural education, issues and perspectives. Boston: Allyn and Bacon.

Ben Rafael, E. \& Peres, Y. (2005). Is Israel one? Nationalism, religion and multiculturalism confounded. Leyden and Boston: Brill. (Hebrew).

Betoret, F.D. (2006). Stressors, self-efficacy, coping resources, and burnout among secondary school teachers in Spain. Educational Psychology, 26, 519-539. https://doi.org/10.1080/01443410500342492

Bergan, S. \& Damian, R. (2010). Higher education for modern societies - Competences and values Sjur (Eds). Publishing Council of Europe Higher Education Series No. 15, Council of Europe Publishing, Strasbourg.

Borgogni, L., Russo, S. D., Miraglia, M., \& Vecchione, M. (2013). The role of self-efficacy and job satisfaction on absences from work. European Review of Applied Psychology, 63, 129-136. https://doi.org/10.1016/j.erap.2012.

Carter D. LOCKS, A. M. \& Winkle-Wagner, R. (2014). From When and Where I Enter: Theoretical and Empirical Considerations of Minority Students' Transition to College Higher Education: Handbook of Theory and Research. Springer. https://doi.org/10.1515/njawhe-2014-0011

Chen, G., Gully, S. M., Whiteman, J. K., \& Kilcullen, R. N. (2000). Examination of relationships among trait-like individual differences, state-like individual differences, and learning performance. Journal of Applied Psychology, 85, 835-847. https://doi.org/10.1037/0021-9010.85.6.835

Cherniss, C. (1993). The role of professional self-efficacy in the etiology of burnout. In W. B. Schaufeli, C. Maslach, \& T. Marek (Eds.), Professional burnout: Recent developments in theory and research (pp. 135-149).Washington, DC: Hemisphere. https://doi.org/10.4324/9781315227979-11

Deemer, S. A. (2004). Classroom goal orientation in high school classrooms: Revealing links between teacher beliefs and classroom environments. Educational Research, 46, 73-90. https://doi.org/10.1080/0013188042000178836 
Duran, E., \& Duran. L. B. (2005). Project ASTER: A model staff development program and its impact on early childhood teachers' self-efficacy. Journal of Elementary Science Education, 17(2), 1-12. https://doi.org/10.1007/BF03174677

Friedman, I. \& Kass, E. (2000). Teachers' perceptions of self-efficacy: The concept and its measurement. Jerusalem: Henrietta Szold Institute (Hebrew).

Gibson, S., \& Dembo, M. H. (1984). Teacher efficacy: a construct validation. Journal of Educational Psychology, 76, 569-582. https://doi.org/10.1037/0022-0663.76.4.569

Goddard, R.D. \& Goddard Y.L. (2001). A multilevel analysis of the relationship between teachers and the collective efficacy in urban schools. Teaching and Teacher Education, 17, 807-818. https://doi.org/10.1016/S0742-051X(01)00032-4

Gay, G. (2010). Culturally Responsive Teaching: Theory, research \& practice. New York; NY: Teachers College Press.

Gladi, B. (2001). Education for Multiculturalism in the State of Israel: Reality or Vision? Ashalim.

Guo, Y., Dynia, J. M. Pelatti, C. Y., Justice L. M. (2014). Self-efficacy of early childhood special education teachers: links to classroom quality and children's learning for children with language impairment. Teaching and Teacher Education, 39, 12-21. https://doi.org/10.1016/j.tate.2013.11.00

Ippolito, K. (2007). Promoting intercultural learning in a multicultural university: ideals and realities. Teaching in higher education, 12(5), 749-763. https://doi.org/10.1080/13562510701596356

Judge, T.A., Jackson, C.L., Shaw, J.C., Scott, B.A. \& Rich, B.L. (2007). Self-efficacy and work-related performance: The integral role of individual differences. Journal of Applied Psychology, 92(1), 107- 127. https://doi.org/10.1037/0021-9010.92.1.107

Kanfer, R. (1990). Motivation theory and industrial and organizational psychology. In M. D. Dunnette \& L. M. Hough (Eds.), Handbook of industrial and organizational psychology (pp. 75-170). Palo Alto, CA: Consulting Psychologists Press.

Kimmel, K. \& Volet, S. (2012). University Students' Perceptions of and Attitudes Towards Culturally Diverse Group Work: Does Context Matter? Journal of Studies in International Education, 16(2) 157-181. https://doi.org/10.1177/1028315310373833

Lev Ari, L. \& Chassisi-Sabak, R. (2016). Meeting with "others" in institutions of higher education. Toward intercultural Efficacy? Research report. Tel Aviv: Mofet, Masa portal.

Mena, J. A., \& Rogers, M. R. (2017). Factors associated with multicultural teaching competence: Social justice orientation and multicultural environment. Training and Education in Professional Psychology, 11(2), 61-68. https://doi.org/10.1037/tep0000143

Morey \& Ma, 2016 Climate change adaptation: factors influencing Chinese smallholder farmers' perceived self-efficacy and adaptation intent. Regional Environmental Change, 17, 171-186. https://doi.org/10.1007/s10113-016-0975-6

Ndura, E.; \& Dogbevia, M. K. (2013). Re-envisioning Multicultural Education in Diverse Academic Contexts. Procedia -Social and Behavioral Sciences, 93, 1015-1019. https://doi.org/10.1016/j.sbspro.2013.09.321

Peng, Y., \& Mao, C. (2015). The impact of person-job fit on job satisfaction: the mediator role of Self efficacy. Social Indicators Research, 121, 805-813. https://doi.org/10.1007/s11205-014-0659-x

Prieto, L. R. (2012). Initial factor analysis and cross-validation of the Multicultural Teaching Competencies Inventory. Journal of Diversity in Higher Education, 5(1), 50-62. https://doi.org/10.1037/a0026199

Ross, J. A. (1995). Strategies for enhancing teachers' belief in their effectiveness: Research on a school improvement hypothesis. Teacher College Record, 97, 227-251.

Saks, A. M. (1995). Longitudinal field investigation of the moderating and mediating effects of self-efficacy on the relationship between training and newcomer adjustment. Journal of Applied Psychology, 80, 211-225. https://doi.org/10.1037/0021-9010.80.2.211

Skaalvik, E. M., \& Skaalvik, S. (2007). Dimensions of Teacher Self-Efficacy and Relations with Strain Factors, Perceived E. M. Skaalvik, S. Skaalvik 1799 Collective Teacher Efficacy, and Teacher Burnout. Journal of Educational Psychology, 99, 611-625. https://doi.org/10.1037/0022-0663.99.3.611 
Schunk, D. H., \& Meece, J. L. (2006). Self-Efficacy Development in Adolescence. In F. Pajares, \& T. Urdan (Eds.), Self-Efficacy Beliefs of Adolescents (pp. 71-96). Greenwich, CT: Information Age Publishing.

Sela-Shayovitz, R. (2009). Dealing with School Violence: The effect of training for prevention of school violence on teachers' perceived self-efficacy in dealing with violent events. Teaching and Teacher Education, 25, 10611066. https://doi.org/10.1016/j.tate.2009.04.010

Spring, J. (2017). The Intersection of Cultures Multicultural Education in the United States and the Global Economy. New York: Routledge. https://doi.org/10.4324/9781351226301

Strayhorn, T. L. (2012). College students' sense of belonging: A key to educational success for all students. New York, NY: Routledge. https://doi.org/10.4324/9780203118924

Tschannen-Moran, M., \& Woolfolk-Hoy, A. (2007). The differential antecedents of self-efficacy beliefs of novice and experienced teachers. Teaching and Teacher Education, 23, 944-956. https://doi.org/10.1016/j.tate.2006.05.003

Tobin, T.J., Muller, R. O. \& Turner, L.M. (2006). Organizational learning and climate as predictors of self-efficacy. Social Psychology of Education, 9, 301-319. https://doi.org/10.1007/s11218-005-4790-z

Wang, H. Hall, N.C. Rahimi, S. (2015). Self-efficacy and causal attributions in teachers: effects on burnout, job satisfaction, illness and quitting intentions. Teaching and Teachers Education, 47, 120-130. https://doi.org/10.1016/j.tate.2014.12.005

Yogev, A. (2001). Approaches to value-based education in a pluralistic society. In: Y. Iram, Y. Cohen, S.A. Schachter and S. Shkolnikov (eds.), Junctures: Values and Education in Israeli Society, pp. 355-379 (Jerusalem: Ministry of Education).

Zee, M. Koomen, F.c. Jellesma, F.C. Grrrling, J. \& Jong P.F. (2016). Inter and intra -individual differences in teachers' self-efficacy: A multilevel factor exploration. Journal of school psychology, 55, 39-56. https://doi.org/10.1016/j.jsp.2015.12.003

Zimmerman, B. J., \& Cleary, T. J. (2006). Adolescents' Development of Personal Agency. The Role of Self-Efficacy Beliefs and Self-Regulatory Skills. In F. Pajares, \& T. Urdan (Eds.), Self-Efficacy Beliefs of Adolescents (pp. 45-69). Greenwich: Information Age. 